Szkoła Główna Gospodarstwa Wiejskiego

w Warszawie

marcin_wysokinski@sggw.pl

ARKADIUSZ GROMADA

Szkoła Główna Gospodarstwa Wiejskiego

w Warszawie

arkadiusz_gromada@sggw.pl

\title{
ENERGY MANAGEMENT SYSTEM AS AN EXAMPLE OF SUSTAINABLE DEVELOPMENT
}

\section{SYSTEMOWE ZARZĄDZANIE ENERGIĄ JAKO PRZYKŁAD ZRÓWNOWAŻONEGO ROZWOJU}

\begin{abstract}
Presentation of system energy management (SZE) as an example of sustainable development. Analyzing the number of valid ISO 50001: 2011 certificates in the world, mainly in European Union countries.

Secondary research materials were used - literature on the subject and data from the survey conducted by ISO.

The number of issued ISO 50001: 2011 certificates annually increases. This applies to most countries of the European Union. The largest number of valid certificates concerns the sector of metals and metal products, the food products sector and the sector of rubber and plastic products. The countries of the European Union with the largest number of valid certificates are Germany, Great Britain and Italy.

Obtaining the ISO 50001 certificate means introducing in the enterprise systemic energy management and implementation of the assumptions of the seventh goal of sustainable development: clean and available energy. With this type of action it is possible to reduce the cost of doing business, reduce energy consumption in the enterprise, and reduce emissions of environmentally harmful substances.
\end{abstract}

\section{STRESZCZENIE}

Celem artykułu było przedstawienie systemowego zarządzania energią (SZE) jako przykładu zrównoważonego rozwoju. W artykule dokonano także analizy liczby ważnych certyfikatów ISO 50001:2011 na świecie, głównie w krajach Unii Europejskiej. W artykule wykorzystano materiały badawcze o charakterze wtórnym 
- literaturę przedmiotu oraz dane pochodzące $\mathrm{z}$ ankiety przeprowadzonej przez ISO. Przeprowadzone badania pozwalają stwierdzić, że liczba wydawanych certyfikatów ISO 50001:2011 rokrocznie wzrasta i dotyczy to większości krajów Unii Europejskiej. Uzyskanie tego certyfikatu oznacza wprowadzanie w przedsiębiorstwie systemowego zarządzania energią i realizowanie założeń siódmego celu zrównoważonego rozwoju: czysta i dostępna energia. Dzięki tego typu działaniom możliwe jest zmniejszenie kosztów prowadzenia działalności gospodarczej, zmniejszenie zużycia energii w przedsiębiorstwie, jak i obniżenie emisji substancji szkodliwych dla środowiska.

KEYWORDS: energy, energy management system, sustainable development, ISO 50001:2011, Poland

SŁOWA KLUCzOWE: energia, systemowe zarządzanie energia, zrównoważony rozwój, ISO 50001:2011

\section{WPROWADZENIE}

W obliczu rosnącego uzależnienia od importu nośników energii oraz ograniczoności zasobów energetycznych, jak również konieczności spowolnienia negatywnych zmian klimatycznych ważnym obszarem zainteresowań gospodarki i naukowców stają się zagadnienia efektywności energetycznej gospodarki, w szczególności poszukiwania rozwiązań umożliwiających oszczędzanie energii (Gołasa i in., 2015; Wysokiński i in., 2014). W Dyrektywie Parlamentu Europejskiego i Rady 2012/27/UE z dnia 25 października 2012 w sprawie efektywności energetycznej ${ }^{1}$ zawarto m.in. uwagę, iż przestawienie się na bardziej efektywną energetycznie gospodarkę powinno doprowadzić do szybszej popularyzacji innowacyjnych rozwiązań technologicznych oraz poprawy konkurencyjności przemysłu w Unii, pobudzenia wzrostu gospodarczego i tworzenia wysokiej jakości miejsc pracy w sektorach związanych z efektywnością energetyczną (Dyrektywa..., 2012). Wspomniana Dyrektywa, poprzez ustanowienie wspólnej struktury ramowej w celu obniżenia o $20 \%$ zużycia energii pierwotnej w UE, stanowi istotny czynnik wpływający na powodzenie realizacji unijnej strategii energetycznej na rok 2020. Dokument wskazuje środki pozwalające stworzyć odpowiednie warunki do poprawy efektywności energetycznej również po tym terminie. Ponadto dyrektywa określa zasady, na jakich powinien funkcjonować rynek energii tak, aby wyeliminować m.in. wszelkie nieprawidłowości ograniczające efektywność do- 
staw. Akt prawny przewiduje także ustanowienie krajowych celów w zakresie efektywności energetycznej na rok 2020. Systemowe zarządzanie energią jest narzędziem, które może wesprzeć osiąganie założonych celów, jak również prowadzić do bezpośrednich korzyści ekonomicznych i środowiskowych.

\section{ZAŁOŻENIA KONCEPCJI ZRÓWNOWAŻONEGO ROZWOJU}

Zrównoważony rozwój to rozwój zaspokajający aktualne potrzeby w taki sposób, aby nie ograniczyć możliwości realizacji potrzeb przyszłych pokoleń. Kluczowym elementem tej definicji, rozpowszechnionej dzięki raportowi Światowej Komisji G.H. Brundtland do spraw Środowiska i Rozwoju pt. OurCommonFuture (WCED, 1987), są:

- potrzeby, w szczególności podstawowe potrzeby ludzi ubogich, które powinny być traktowane $z$ najwyższym priorytetem, oraz

- ograniczenia, narzucane przez rozwój technologii oraz społeczeństw, wpływające na zdolność zaspokajania obecnych i przyszłych potrzeb.

Według wspomnianego wyżej raportu, aby zapewnić rozwój społeczny oraz ekonomiczny każdego z państw świata, cele polityki społeczno-ekonomicznej powinny być kształtowane z uwzględnieniem koncepcji zrównoważonego rozwoju. Raport OurCommonFuture, opublikowany w 1987 roku przez ONZ za pośrednictwem Oxford University Press, był kolejnym punktem zwrotnym w rozwoju międzynarodowej polityki ekologicznej. Ruch ten zapoczątkowany został w 1972 roku na Konferencji Sztokholmskiej ONZ (UN, 1972).

Po roku 1987 nastąpiła eskalacja zainteresowania koncepcją zrównoważonego rozwoju, mająca odzwierciedlenie w dokumencie Agenda 21 (UN, 1993), opublikowanym na Szczycie Ziemi w 1992 roku oraz w Deklaracji Milenijnej Narodów Zjednoczonych (UN, 2000), w której określone zostały tzw. Milenijne Cele Rozwoju, które stanowiły zobowiązanie społeczności międzynarodowej, m.in. do redukcji ubóstwa i głodu, poprawy stanu edukacji oraz zdrowia, zrównania statusu kobiet i mężczyzn oraz ochrony środowiska naturalnego. Termin realizacji tych celów ustalony był na 2015 rok, jednak właśnie w tym roku Milenijne Cele Rozwoju zostały zastąpione przez Cele Zrównoważonego Rozwoju (rys. 1), które zawarte zostały w Agendzie Rozwojowej 2030 Transforming our world (UN, 2015). 
Rysunek 1.

Cele zrównoważonego rozwoju
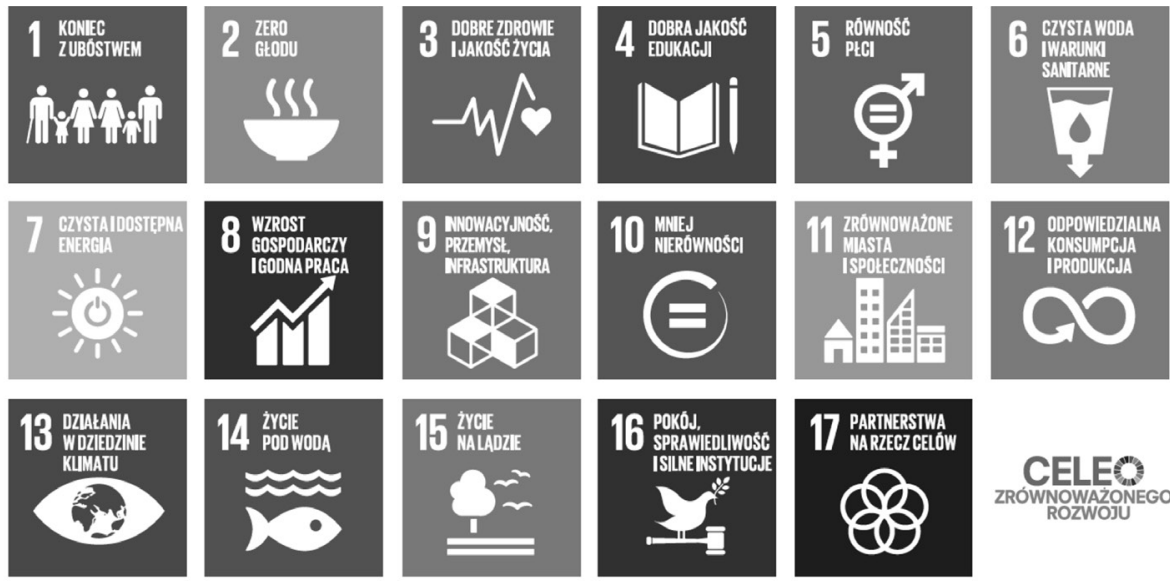

Źródło: http://www.un.org.pl/download

W skład 17 Celów Zrównoważonego Rozwoju wchodzi 169 zadań (dla porównania 8 Milenijnych Celów Rozwoju zawierało 21 zadań). Realizacja tych celów będzie monitorowana i analizowana za pomocą zestawu globalnych wskaźników (UNIC, 2015). Zostaną one uzupełnione wskaźnikami na poziomie regionalnym oraz krajowym, które opracowane będą przez państwa członkowskie Organizacji Narodów Zjednoczonych. Dnia 11 maja 2018 roku zaktualizowana została klasyfikacja poziomów poszczególnych wskaźników, które dzielą się na trzy poziomy (IAEG-SDGs, 2018):

- Poziom 1: koncepcja wskaźnika jest klarowna, posiada on międzynarodowo ustaloną metodologię oraz standardy, zaś dane są regularnie dostarczane przez co najmniej 50\% krajów, dla których dany wskaźnik jest istotny.

- Poziom 2: koncepcja wskaźnika jest klarowna, posiada on międzynarodowo ustaloną metodologię oraz standardy, jednak dane nie są regularnie dostarczane przez kraje.

- Poziom 3: dla wskaźnika nie ma dostępnych międzynarodowych metod oraz standardów, jednak będą one opracowywane/testowane. 
Wśród celów wyróżnić można cel 7: zapewnienie wszystkim ludziom dostępu do przystępnej cenowo, niezawodnej, zrównoważonej i nowoczesnej energii. W celu tym zawartych jest 5 celów szczegółowych, które powinny być zrealizowane do 2030 roku (UN, 2015):

7.1: Zapewnienie powszechnego dostępu do niedrogich, niezawodnych i nowoczesnych usług energetycznych.

7.2: Zwiększenie udziału energii odnawialnej w globalnym miksie energetycznym.

7.3: Podwojenie globalnej stopy poprawy efektywności energetycznej.

7.a: Wzmocnienie współpracy międzynarodowej, która pozwoli na przeprowadzanie badań oraz tworzenie technologii w zakresie czystej energii, w tym energii odnawialnej, efektywności energetycznej oraz zaawansowanej i czystszej technologii pozyskiwania paliw kopalnych, a także pozwoli promować inwestycje w infrastrukturę energetyczną i czystą technologię energetyczną.

7.b: Rozbudowanie infrastruktury i ulepszenie technologii dostarczania nowoczesnych i zrównoważonych usług energetycznych dla wszystkich w krajach rozwijających się, w szczególności w krajach najmniej rozwiniętych, małych rozwijających się państwach wyspiarskich i śródlądowych krajach rozwijających się, zgodnie $\mathrm{z}$ odpowiednimi programami wsparcia.

Cele te będą monitorowane i analizowane za pomocą poniższych wskaźników (IAEG-SDGs, 2018):

- Cel szczegółowy 7.1:

- odsetek ludności z dostępem do elektryczności (poziom 1),

- odsetek ludności zależnych od czystych paliw i technologii (poziom 1),

- Cel szczegółowy 7.2:

- udział energii odnawialnej w całkowitym finalnym zużyciu energii (poziom 1),

- Cel szczegółowy 7.3:

- energochłonność mierzona w kategoriach energii pierwotnej i PKB (poziom 1),

- Cel szczegółowy 7.a:

- międzynarodowe przepływy finansowe do krajów rozwijających się w celu wspierania badań i rozwoju w dziedzinie czystej energii oraz produkcji energii odnawialnej (poziom 3), 
- Cel szczegółowy 7.b:

- inwestycje w efektywność energetyczną, będącą stosunkiem PKB i kwoty bezpośrednich inwestycji zagranicznych w transfer finansowy w infrastrukturę oraz technologie, dotyczące usług zrównoważonego rozwoju (poziom 3).

\section{AUDYT ENERGETYCZNY JAKO PIERWSZY KROK DO WPROWADZENIA SYSTEMU ZARZĄDZANIA ENERGIĄ W PRZEDSIĘBIORSTWIE}

Audyt energetyczny oznacza systematyczną procedurę, której celem jest uzyskanie odpowiedniej wiedzy o profilu istniejącego zużycia energii danego budynku lub zespołu budynków, działalności lub instalacji przemysłowej bądź handlowej lub usługi prywatnej lub publicznej, określenie, w jaki sposób i w jakiej ilości możliwe jest uzyskanie opłacalnej oszczędności energii, oraz poinformowanie o wynikach (Dyrektywa 2012/27/UE). Zgodnie z Ustawą z dnia 20 maja 2016 r. o efektywności energetycznej obowiązkiem przedsiębiorcy, z wyjątkiem mikroprzedsiębiorcy, małego lub średniego przedsiębiorcy (w rozumieniu Ustawy z dnia 2 lipca 2004 r. o swobodzie działalności gospodarczej), jest przeprowadzenie co 4 lata audytu energetycznego przedsiębiorstwa. Procedura audytu składa się z sekwencji procedur, których celem jest (Audyt..., 2018):

- rozpoznanie źródeł strat energii, egzergii ${ }^{2}$ i czynnika w obiegu,

- ustalenie poziomu odniesienia w stosunku do obecnych rozwiązań technicznych w tej dziedzinie,

- zaproponowanie przedsięwzięć, które zminimalizują wcześniej rozpoznane straty,

- realizacja prostej analizy w celu określenia podstawowych wskaźników ekonomicznych dla zaproponowanych przedsięwzięć.

Audyt energetyczny może być przeprowadzony na różnych poziomach. Najniższy z nich obejmuje jedynie krótką inspekcję w przedsiębiorstwie oraz szeroką ocenę wejścia i wyjścia energii z systemu. Pozwala to na określenie nisko kosztowych oszczędności energii w przedsiębiorstwie. Audyt na średnim poziomie obejmuje dogłębną analizę kosztów energii, zużycia energii 
i charakterystyki systemu wraz z pomiarami zapotrzebowania na energię w celu zidentyfikowania środków efektywności energetycznej, które są bardziej kapitałochłonne i muszą być dostosowane do planu budżetu finansowego. Najbardziej zaawansowany poziom, określany jako audyt na poziomie inwestycyjnym, obejmuje dodatkowy ciągły monitoring danych systemowych i charakterystyk procesów.

Audyty energetyczne na tak kompleksowych poziomach mogą również stanowić ważną podstawę lub pierwszy krok do wprowadzenia i ustanowienia systemów zarządzania energią (SZE) w przedsiębiorstwach/innych instytucjach. Umożliwiają efektywne zarządzanie zapotrzebowaniem i zużyciem energii w zakładach produkcyjnych lub przetwórczych - również w rolniczych łańcuchach wartości - Międzynarodowy Standard SZE: ISO 50001 (PAEGC, 2017).

\section{SYSTEMOWE ZARZĄDZANIE ENERGIĄ (SZE)}

Standard PN-EN ISO 50001:2012 to zestaw wytycznych, które pozwalają określić elementy systemu zarządzania energią w każdej organizacji. W normie przedstawiona jest także metodyka efektywnego wdrażania tych wytycznych, co w ostateczności ma przyczynić się w organizacji do poprawy wyniku energetycznego, obniżenia kosztów energii oraz stopnia oddziaływania na środowisko. ISO 50001 zapewnia organizacjom uznane na arenie międzynarodowej ramy wdrażania systemu zarządzania energią (SZE). Standard odnosi się do następujących kwestii (About ISO..., 2018):

- zużycie energii,

- pomiar, dokumentacja i raportowanie zużycia energii,

- praktyki projektowania i zakupów dla urządzeń, systemów i procesów wykorzystujących energię,

- wszystkie zmienne wpływające na wydajność energetyczną, które mogą być monitorowane i na które wpływa organizacja.

ISO 50001 oparty jest na strukturze Plan-Do-Check-Act:

- Plan - planuj, czyli wykonuj audyty, wyznaczaj cele,

- Do - wykonaj, czyli wdrażaj programy poprawy efektywności energetycznej, 
- Check - sprawdzaj, czyli mierz i monitoruj,

- Act - działaj, czyli doskonal system.

Zapewnia to ciągłe doskonalenie organizacji wraz z ISO 9001 (zarządzanie jakością), ISO 14001 (zarządzanie środowiskiem) i innymi systemami zarządzania. ISO 50001 został zaprojektowany tak, aby być kompatybilnym z innymi systemami zarządzania. Na rysunku 2 przedstawiono model systemu zarządzania energią według normy ISO 50001:2012.

Rysunek 2 .

\section{Model systemu zarządzania energią}

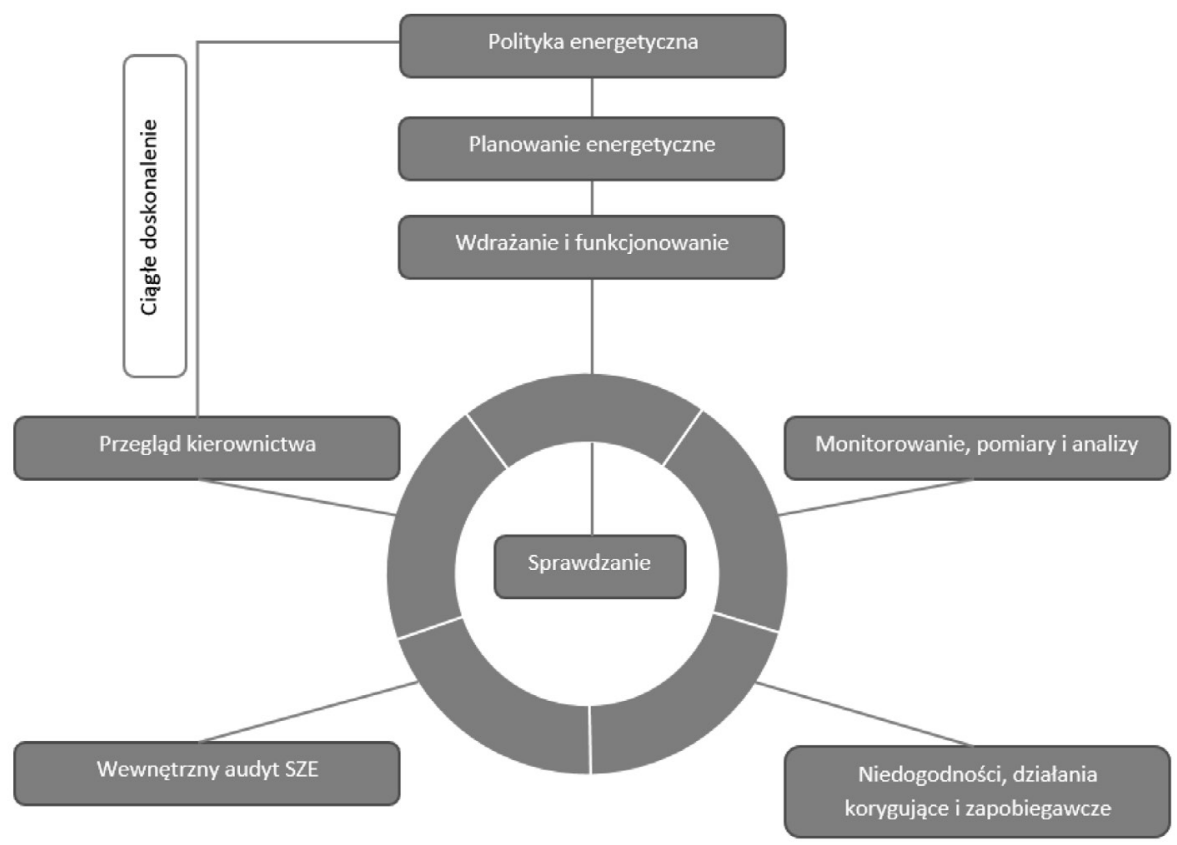

Źródło: opracowanie własne na podstawie (ISO, 2011).

Główni odbiorcy standardu to zarówno instytucje publiczne, jak i firmy, zaczynając od małych zakładów, a kończąc na dużych przedsiębiorstwach, często związanych z energetyką. Przegląd energetyczny, będący składową 
SZE, pozwala przedsiębiorstwom zobligowanym do przeprowadzenia co 4-letniego audytu spełnić wymagania wynikające z przyjętej w 2016 roku ustawy o efektywności energetycznej.

Norma nie określa minimalnych kryteriów wydajności, redukcji zużycia energii ani celów, jednak wymaga od organizacji i obiektu, aby wykazać ciągłą poprawę wydajności energetycznej. Organizacja sama określa zakres i granice funkcjonowania systemu. Na etapie tworzenia polityki energetycznej przedsiębiorstwa definiowane są zasady i kierunki działań, zaś kierownictwo dodatkowo określa, w jaki sposób założone cele zostaną zrealizowane oraz w jaki sposób polityka energetyczna w przedsiębiorstwie będzie stale doskonalona.

Skuteczne wdrożenie systemu zarządzania energią niesie ze sobą wiele korzyści dla przedsiębiorstwa, do których zaliczyć można między innymi (Systemy..., 2018):

- oszczędność energii,

- zmniejszenie kosztów funkcjonowania przedsiębiorstwa,

- spadek emisji szkodliwych substancji,

- zwiększenie świadomości pracowników firmy w kwestii ograniczania konsumpcji energii,

- prawidłowo prowadzona gospodarka energetyczna oraz systematyzacja działań z tym związana,

- tworzenie wizerunku organizacji, jako odpowiedzialnej i świadomej w zakresie efektywnego zarządzania energią.

\section{WDRAŻANIE ISO 50001 NA ŚWIECIE}

W tabeli 1 przedstawiona została liczba ważnych certyfikatów ISO 50001:2011 na świecie i w Polsce w latach 2015-2016 oraz liczba obiektów, których te certyfikaty dotyczą. 
Tabela 1.

Liczba ważnych certyfikatów na świecie w latach 2015-2016 oraz liczba obiektów związanych z certyfikatami

\begin{tabular}{|c|c|c|c|c|c|c|}
\hline & \multicolumn{3}{|c|}{ Certyfikaty } & \multicolumn{3}{c|}{ Obiekty } \\
\cline { 2 - 7 } & $\mathbf{2 0 1 5}$ & $\mathbf{2 0 1 6}$ & $\begin{array}{c}\text { Zmiana } \\
\mathbf{w \%}\end{array}$ & $\mathbf{2 0 1 5}$ & $\mathbf{2 0 1 6}$ & $\begin{array}{c}\text { Zmiana } \\
\text { w \% }\end{array}$ \\
\hline $\begin{array}{c}\text { ISO 50001:2011 } \\
\text { na świecie }\end{array}$ & 11985 & 20216 & $69 \%$ & 20562 & 23377 & $14 \%$ \\
\hline $\begin{array}{c}\text { ISO 50001:2011 } \\
\text { w Polsce }\end{array}$ & 74 & 112 & $51 \%$ & 63 & 74 & $17 \%$ \\
\hline
\end{tabular}

Źródło: opracowanie własne na podstawie (ISO, 2017).

Wykres 1.

Liczba certyfikatów w poszczególnych regionach świata w latach 2015-2016 25000

\section{Afryka; 40}

Ameryka Północna; 77

20000

$$
\begin{aligned}
& \text { Ameryka Południowa } \\
& \text { iŚrodkowa; } 92 \\
& \text { Bliski Wschód; } 130
\end{aligned}
$$

15000

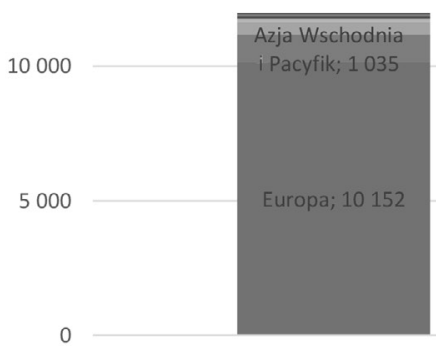

2015
Azja Południowa

i Środkowa; 459

Źródło: opracowanie własne na podstawie (ISO, 2017).

Ameryka Północna; 73

Ameryka Południowa

i Środkowa; 81

Bliski Wschód; 153

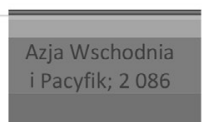

Azja Południowa

i Środkowa; 663

Liczba ważnych certyfikatów ISO 50001:2011 na świecie w 2015 roku wyniosła 11985. Certyfikaty te dotyczyły 20562 obiektów. W kolejnym roku liczba certyfikatów zwiększyła się o 69\% (wzrost o 8231 certyfikatów), co świadczy o rosnącej popularności. W mniejszym stopniu wzrosła liczba obiektów. Różnica między 2015 a 2016 rokiem wyniosła 14\% (wzrost o 2815 
obiektów). W Polsce w 2016 roku było 112 ważnych certyfikatów, związanych z 74 obiektami. Było to odpowiednio o 51\% i 17\% więcej niż w roku poprzednim. Najwięcej ważnych certyfikatów w 2016 roku było w Niemczech (9024 certyfikaty), Wielkiej Brytanii (2829), Włoszech (1415), Chinach (1015) oraz Francji (759).

Na wykresie 1 przedstawiona została liczba ważnych certyfikatów w poszczególnych regionach świata w latach 2015-2016.

Zdecydowanym liderem pod względem ważnych wydanych certyfikatów jest Europa. Ich liczba w 2016 roku wyniosła 17102 i była wyższa o 68\% niż w roku poprzednim. Największy wzrost (102\%) odnotowano z kolei w regionie Azji Wschodniej i Pacyfiku. W dwóch regionach: Ameryka Południowa i Środkowa oraz Ameryka Północna spadła liczba ważnych certyfikatów, odpowiednio o $12 \%$ i $5 \%$.

W tabeli 2 przedstawionych zostało 10 sektorów przemysłowych z największą liczbą ważnych certyfikatów w latach 2015-2016.

Tabela 2.

Sektory przemysłowe z największą liczbą ważnych certyfikatów w latach 2015-2016

\begin{tabular}{|c|c|c|}
\hline Sektor przemysłowy & $\mathbf{2 0 1 5}$ & $\mathbf{2 0 1 6}$ \\
\hline Metale i wyroby metalowe & 919 & 1052 \\
\hline Produkty spożywcze, napoje i tytoń & 876 & 805 \\
\hline Wyroby z gumy i tworzyw sztucznych & 672 & 764 \\
\hline Chemikalia, produkty chemiczne i włókna & 583 & 763 \\
\hline Inne usługi & 234 & 662 \\
\hline Sprzęt elektryczny i optyczny & 312 & 376 \\
\hline Budownictwo & 145 & 367 \\
\hline Energia elektryczna & 210 & 359 \\
\hline Transport, gospodarka magazynowa i komunikacja & 98 & 328 \\
\hline Maszyny i urządzenia & 203 & 305 \\
\hline OGÓŁEM & 6600 & 8667 \\
\hline
\end{tabular}

Źródło: opracowanie własne na podstawie (ISO, 2017). 
Tabela 3.

Liczba ważnych certyfikatów w poszczególnych krajach Unii Europejskiej w latach 2015-2016 oraz liczba obiektów związanych z certyfikatami

\begin{tabular}{|c|c|c|c|c|}
\hline \multirow{2}{*}{ Kraj } & \multicolumn{2}{|c|}{ Certyfikaty } & \multicolumn{2}{|c|}{ Obiekty } \\
\hline & 2015 & 2016 & 2015 & 2016 \\
\hline Niemcy & 5931 & 9024 & 6390 & 6874 \\
\hline Wielka Brytania & 1464 & 2829 & 1316 & 1931 \\
\hline Włochy & 470 & 1415 & 853 & 1748 \\
\hline Francja & 500 & 759 & 8917 & 6271 \\
\hline Węgry & 68 & 546 & 41 & 522 \\
\hline Hiszpania & 390 & 465 & 614 & 862 \\
\hline Czechy & 73 & 369 & 142 & 658 \\
\hline Austria & 220 & 224 & 187 & 185 \\
\hline Irlandia & 91 & 137 & 83 & 176 \\
\hline Dania & 55 & 118 & 37 & 115 \\
\hline Polska & 74 & 112 & 63 & 74 \\
\hline Szwecja & 85 & 88 & 75 & 65 \\
\hline Słowacja & 36 & 73 & 27 & 24 \\
\hline Belgia & 43 & 70 & 20 & 55 \\
\hline Holandia & 37 & 64 & 19 & 67 \\
\hline Chorwacja & 21 & 55 & 25 & 51 \\
\hline Grecja & 45 & 51 & 14 & 23 \\
\hline Finlandia & 30 & 44 & 5 & 5 \\
\hline Portugalia & 38 & 37 & 11 & 25 \\
\hline Rumunia & 69 & 33 & 6 & 5 \\
\hline Łotwa & 18 & 28 & 11 & 23 \\
\hline Bułgaria & 22 & 27 & 262 & 267 \\
\hline Słowenia & 10 & 23 & 7 & 20 \\
\hline Luksemburg & 6 & 10 & 8 & 8 \\
\hline Litwa & 6 & 6 & 2 & 2 \\
\hline Malta & 1 & 6 & 1 & 12 \\
\hline Cypr & 7 & 5 & 4 & 1 \\
\hline Estonia & 4 & 2 & 4 & 2 \\
\hline
\end{tabular}

Źródło: opracowanie własne na podstawie (ISO, 2017). 
Największa liczba ważnych certyfikatów w 2016 roku dotyczyła sektora metali i wyrobów metalowych - były to 1052 certyfikaty, o 14\% więcej niż w 2015 roku. Na drugim miejscu znajdował się sektor produktów spożywczych, napoi oraz tytoniu (805 certyfikatów). Sektor ten, jako jedyny w TOP 10, odnotował spadek liczby ważnych certyfikatów (o 8\%). Największy wzrost liczby certyfikatów stwierdzono w sektorze transportu, gospodarki magazynowej i komunikacji - liczba certyfikatów wzrosła z 98 do 328 (zmiana o 235\%).

W tabeli 3 przedstawiona została liczba ważnych certyfikatów w poszczególnych krajach Unii Europejskiej w latach 2015-2016 oraz obiektów, których certyfikaty te dotyczyły.

Krajem liderującym w 2016 roku w Unii Europejskiej zarówno pod względem ważnych certyfikatów, jak i obiektów, których certyfikaty te dotyczyły, były Niemcy. Były to 9024 certyfikaty oraz 6874 obiekty. W porównaniu z 2015 rokiem liczby te wzrosły odpowiednio o 52\% i 8\%. Krajem z największym przyrostem liczby certyfikatów były Węgry (703\%, wzrost z 68 do 546). W 4 krajach liczba certyfikatów spadła. Były to: Rumunia (-52\%), Estonia (-50\%), Cypr (-29\%) oraz Portugalia (-3\%). Węgry były także krajem z największym przyrostem obiektów związanych z certyfikatami - ich liczba wzrosła w 2016 roku o 1173\% w porównaniu z 2015 rokiem (wzrost z 41 do 522 obiektów). Równie wysoki wzrost odnotowano na Malcie (1100\%, wzrost z 1 do 12 obiektów). W krajach takich jak Francja, Austria, Szwecja, Słowacja, Rumunia, Cypr oraz Estonia liczba obiektów się zmniejszyła.

\section{Podsumowanie}

1. Rozwój koncepcji zrównoważonego rozwoju przyczynił się do uszczegółowienia zadań, których realizacja monitorowana będzie za pomocą zestawu globalnych wskaźników. Zadania te wchodzą w skład 17 Celów Zrównoważonego Rozwoju, wśród których wyróżnić można Cel 7 - Czysta i dostępna energia.

2. Realizacja ww. celu możliwa jest m.in. dzięki przeprowadzaniu w przedsiębiorstwach audytu energetycznego, złożonego z szeregu procedur, mających na celu zwiększenie efektywności energetycznej w przedsiębiorstwie. Jest to zarazem pierwszy krok do wprowadzenia systemu zarządzania energią w organizacji. 
3. Systemowe zarządzanie energią oparte jest na normie ISO 50001:2011, tworzącej ramy pozwalające na jego wdrożenie w organizacji. Norma ta zgodna jest $\mathrm{z}$ innymi systemami zarządzania. Istotną cechą normy ISO 50001:2011 jest to, że nie zostały w niej określone minimalne kryteria dotyczące wydajności czy też redukcji zużycia energii.

4. Wdrożenie systemu zarządzania energią niesie za sobą wiele korzyści. Coraz większa liczba obiektów na świecie objęta jest certyfikacją ISO 50001:2011. W 2016 roku liczba certyfikatów wyniosła 20116 i była o 69\% większa niż w 2015 roku. Również w Polsce wzrosła liczba ważnych certyfikatów oraz obiektów objętych certyfikacją. Przyrost liczby certyfikatów w 2016 roku wyniósł 51\%, zaś liczby obiektów 17\%. Liderem w obu zestawieniach w Unii Europejskiej były Niemcy, posiadający w 2016 roku 9024 ważnych certyfikatów oraz 6874 obiektów.

\section{Literatura}

About ISO 50001 and DOE, https://www.energy.gov/eere/amo/about-iso-50001-and-doe (dostęp: 28.05.2018).

Audyt efektywności energetycznej (Energy Efficiency Audit), http://www.bialecertyfikaty.com.pl/audyt-efektywnosci-energetycznej (dostęp: 28.05.2018).

Dyrektywa Parlamentu Europejskiego i Rady 2012/27/UE z dnia 25 października 2012 r. w sprawie efektywności energetycznej, zmiany dyrektyw 2009/125/ WE i 2010/30/UE oraz uchylenia dyrektyw 2004/8/WE i 2006/32/WE (Directive 2012/27/EU of the European Parliament and of the Council of 25 October 2012 on energy efficiency, amending Directives 2009/125/EC and 2010/30/EU and repealing Directives 2004/8/EC and 2006/32/EC Text with EEA relevance).

Golasa, P., Wysokiński, M., Bieńkowska-Golasa, W. (2015). Energy Consumption in the Iron \& Steel Industry in EU Member States in Light of the Theory of Environmental Economics, In Metal 2015: 24th International Conference on Metallurgy and Materials, Conference Proceedings. Ostrava: TANGER, 2015, pp. 1927-1932.

Inter-agency and Expert Group on SDG Indicators (IAEG-SDGs) (2018). Tier Classification for Global SDG Indicators, https://unstats.un.org/sdgs/iaeg-sdgs/tier-classification/ (dostęp: 28.05.2018).

International Organization for Standardization (2017). The ISO Survey of Management System Standard Certifications 2016, https://www.iso.org/the-iso-survey.html (dostęp: 28.05.2018). 
International Organization for Standardization (2011). Energy management systems - Requirements with guidance for use, https://www.iso.org/obp/ui/\#iso:std:iso:50001:ed-1:v1:en (dostęp: 28.05.2018).

Powering Agriculture - An Energy Grand Challenge (PAEGC) (2017). Sustainable Energy for Food. Massive Open Online Course - Reader, Deutsche Gesellschaft für Internationale Zusammenarbeit, Bonn, s. 71.

Systemy zarzadzania energia (Energy Management Systems). http://www.bialecertyfikaty.com.pl/systemy-zarzadzania-energia (dostęp: 28.05.2018).

UNIC Warsaw. Ośrodek Informacji ONZ w Warszawie (2015). Zrównoważony rozwój i Cele Zrównoważonego Rozwoju (Sustainable Development and Sustainable Development Goals), http://www.unic.un.org.pl/strony-2011-2015/zrownowazonyrozwoj-i-cele-zrownowazonego-rozwoju/2860 (dostęp: 28.05.2018).

United Nations (UN) (2015). Transforming our world: the 2030 Agenda for Sustainable Development, New York: United Nations Dept. of Public Information.

United Nations (UN) (2000). United Nations Millennium Declaration, New York: United Nations Dept. of Public Information.

United Nations (UN) (1993). Agenda 21: programme of action for sustainable development; Rio Declaration on Environment and Development; Statement of Forest Principles: The final text of agreements negotiated by governments at the United Nations Conference on Environment and Development, 3-14 June 1992, Rio de Janeiro, Bra$z i l$, New York: United Nations Dept. of Public Information.

United Nations (UN) (1972). Report of the United Nations Conference on the Human Environment, Stockholm.

World Commission on Environment and Development (WCED) (1987). Our Common Future, Oxford University Press, Oxford, New York.

Wysokiński, M., Baran, J., Golasa, P., Lenort, R. (2014). Economic and Energy Efficiency of the Mining and Quarrying Sector in European Countries, In Metal 2014: 23th International Conference on Metallurgy and Materials. Ostrava: TANGER, 2014, pp. 1965-1971. 


\section{Endnotes:}

${ }^{1}$ Efektywność energetyczna oznacza stosunek uzyskanych wyników, usług, towarów lub energii do wkładu energii [Dyrektywa].

${ }^{2}$ Egzergia - wyraża minimalną ilość pracy, jaką należy wykonać, by z powszechnie występujących składników otaczającej przyrody wytworzyć wymaganą substancję o wymaganych parametrach, wykorzystując otaczającą przyrodę jako źródło ciepła bezwartościowego pod względem termodynamicznym (J. Szargut, A. Ziębik, Podstawy energetyki cieplnej, PWN, Warszawa 1998). 